\title{
Techniques of CCHP as a right way to apply the 2nd Law of Thermodynamic: case study (Part Two)
}

\author{
Prof. Eng. Francesco Patania1, Prof. Eng. Antonio Gagliano1, \\ Prof. Eng. Francesco Nocera1, Eng. Agrifoglio Antonio2 \\ ${ }^{1}$ Department of Industrial Engineering (DII) \\ Catania University (Italy) \\ e-mail: fpatania@dii.unict.it ; agagliano@dii.unict.it ; fnocera@unict.it \\ ${ }^{2}$ Indipendent researcher \\ e-mail: antonio.agrifoglio@outlook.com
}

\section{Short summary of "Part One"}

"Part one" [1] showed principal characteristics of architecture and plants of a new "Hospital in Catania city" $(\mathrm{CH})$. $\mathrm{CH}$ was designed for about 750 beds for various medical braches; actually the building construction are nearly at the end with a final global cost of around $€ 145,000,000$. Authors were designers of an "Efficient Energy System" (EES) [2] for needs of $\mathrm{CH}$ funded with more than $€ 18,000,000$. "Part one" illustrated :

- $\quad$ Architectural features of buildings (Fig.1).

- Machineries, equipments, CCHP plants and other technological utilities components of the thermodynamic architecture of EES (Fig.2).

Given Italian Regulation Decrees, energy produced by CCHP plant is assimilated to energy produced by renewables energy when production happens in full compliance with well defined parameters as expected in EES design. EES was developed on the basis of " $2^{\text {nd }}$ Law of Thermodynamics" that allows to utilize the same thermal energy coming from one source more times for different supplyings. This is possible if there are different and decreasing intervals of temperatures for each supplying. In this way people obtain significantly energy saving with consequence of a lower amount of wasted energy in comparison with traditional energy system and a lower production too of environmental pollutants.

\section{Abstract \\ Through data of consumption of various kinds of energy expected for operational EES as in executive design, it was possible to calculate the amount of air polluting emission}

$\left(\mathrm{CO}_{2}, \mathrm{NO}_{\mathrm{x}}, \mathrm{PM}_{10}\right)$ produced by energy plants. Similarly it was possible to calculate emissions of the same amount of energy wasted by $\mathrm{CH}$ but in the case of energy supply by conventional technologies and plants. "Part two" of paper shows the result of comparison between emission coming from operational EES and emission in the case of energy supply by conventional technologies and plants. Results demonstrate how much pollution energy supply by EES takes away, that is the environmental advantages achieved.

\section{Key Words}

Energy System, Environment, CCHP, Hospital

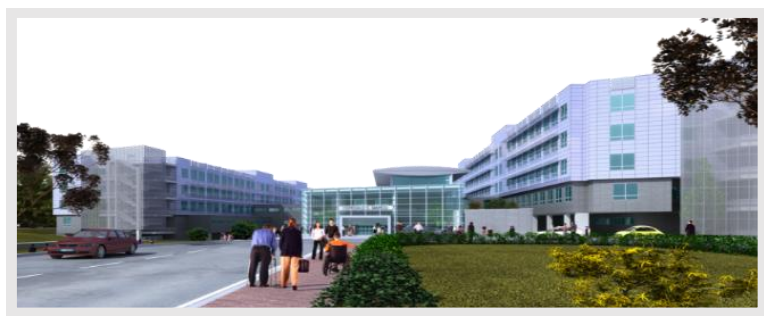

Fig. 1 - CH Perspective Est

\section{Efficient Energy System (EES)}

A gas turbine (Typhoon of Siemens) powered by methane and coupled with an Alternator and an Heat Recovery Steam Generator (HRSG), supplies 5,25 $\mathrm{MW}_{\mathrm{e}}$ electrical power, that is more than amount needed by $\mathrm{CH}$ during operation. Following the basis of " 2 nd Law of Thermodynamics", thermal energy abundantly contained in exhaust of gas turbine, continuously at 
intervals of temperature well-defined and with decreasing values of temperature for each interval, powers a sequence of $\mathrm{CH}$ operational functions. By appropriate heat exchange with water, thermal energy is exploited to produce low pressure steam to power machine based on "cooling absorption cycle" to produce cold water $\left(5 \div 6{ }^{\circ} \mathrm{C}\right)$, to produce hot sanitary water, to produce hot water for various utilities, to feed HVAC plants and so on. Fig. 2 [1] shows the final energy architecture of EES.

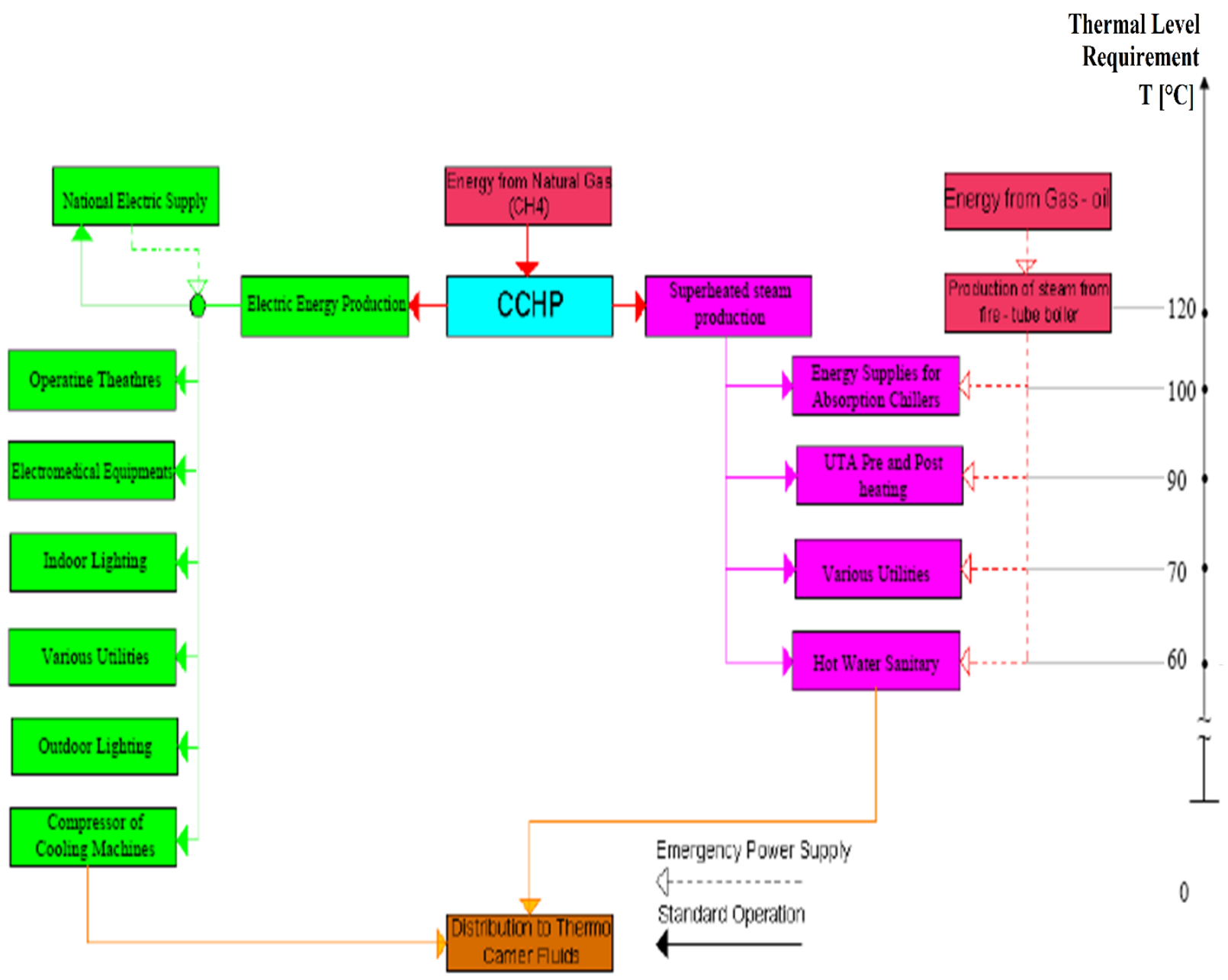

Fig. 2 - Architecture of EES

\section{Energy required from $\mathrm{CH}$}

Table nn. 1, 2, 3 and fig. 3 here after showed are coming from calculations reported in $3^{\text {rd }}$ and $5^{\text {th }}$ paragraphs of "Part one" of paper [1].

Tab. 1 shows the way to calculate the total equivalent hours of operation of CCHP by use of percentage value $(\varepsilon)$ of full load operation in function of expected real operational times (see $3^{\text {rd }}$ paragraph of "Part one").

Tab. 2 shows electrical power request for indoor and outdoor lighting and for various utilities (electrical equipment, etc. etc.) (see $3^{\text {rd }}$ paragraph of "Part one").

Data of Tab. 2 come from a cognitive survey carried out on three Sicilian hospitals about similar as regard volumes of buildings, medical branches and operational electrical data essential to operation of machineries, equipments and so on so as considered in executive design of plants.

Tab.3 shows heat power request for each technical function of $\mathrm{CH}$. Methodology to find data was the same previously illustrated.

Fig. 3 shows in which quantity will supply various kinds of energy in function of utilization of cogeneration group, electrical network, machine at absorption or compression cycle in the case of peak of thermal and electrical request (see $5^{\text {th }}$ paragraph of "Part one" ). 


\begin{tabular}{|c|c|c|c|c|c|}
\hline Months & Days & $\begin{array}{c}\text { Operating } \\
\text { time (h) }\end{array}$ & $\begin{array}{c}\text { \% of full- } \\
\text { load } \\
\text { operation } \boldsymbol{E}\end{array}$ & $\begin{array}{c}\text { Equivalent } \\
\text { time of full- } \\
\text { load (h) }\end{array}$ & $\begin{array}{c}\text { Total } \\
\text { equivalent } \\
\text { (h) }\end{array}$ \\
\hline January & 31 & 24 & 70 & 16,80 & 520,8 \\
\hline February & 28 & 24 & 70 & 16,80 & 470,4 \\
\hline March & 31 & 24 & 70 & 16,80 & 520,8 \\
\hline April & 30 & 24 & 70 & 16,80 & 504,0 \\
\hline May & 31 & 24 & 70 & 16,80 & 520,8 \\
\hline June & 30 & 24 & 100 & 24,0 & 504,0 \\
\hline July & 31 & 24 & 100 & 24,0 & 520,8 \\
\hline August & 31 & 24 & 100 & 24,0 & 520,8 \\
\hline September & 30 & 24 & 70 & 16,80 & 504,0 \\
\hline October & 31 & 24 & 50 & 12,00 & 520,8 \\
\hline November & 30 & 24 & 50 & 12,00 & 504,0 \\
\hline December & 31 & 24 & 50 & 12,00 & 520,8 \\
\hline Total yearly & $\mathbf{3 6 5}$ & $\mathbf{8 . 7 6 0}$ & & & $\mathbf{6 , 1 3 3 . 0}$ \\
\hline
\end{tabular}

Tab. 1 - Equivalent hours of operation of CCHP system (operative turbogas)

\begin{tabular}{|l|ll|}
\hline Unit of air treatment & $815 \quad \mathrm{~kW}_{\mathrm{e}}$ \\
\hline Outdoor lighting & $60 \mathrm{~kW}$ \\
\hline Indoor lighting & $350 \quad \mathrm{~kW}_{\mathrm{e}}$ \\
\hline Electrical medical equipments & $1,200 \mathrm{~kW}$ \\
\hline Centrifugal compressors (n. 14) & $3,219 \mathrm{~kW}$ \\
\hline Medical operation rooms (n. 14) & $560 \quad \mathrm{~kW}$ \\
\hline Various utilities & $936 \quad \mathrm{~kW}$ \\
\hline Total amount & $\mathbf{7 . 1 4 0} \quad \mathbf{k W}$ \\
\hline
\end{tabular}

\begin{tabular}{|l|l|l|l|}
\hline Summer time & {$[\mathbf{k W}]$} & Winter time & {$[\mathbf{k W} \mathbf{t}$} \\
\hline Hot sanitary water & 1,425 & $\begin{array}{l}\text { Hot sanitary } \\
\text { water }\end{array}$ & 1,425 \\
\hline $\begin{array}{l}\text { Cooling batteries for } \\
\text { U.T.A. }\end{array}$ & 538 & $\begin{array}{l}\text { Post heating } \\
\text { (HVAC) }\end{array}$ & 5,650 \\
\hline $\begin{array}{l}\text { Absorption cooling } \\
\text { machines }\end{array}$ & 12,887 & $\begin{array}{l}\text { Hot separated } \\
\text { circuits }\end{array}$ & 1,415 \\
\hline Various utilities & 1,650 & Various utilities & 1,650 \\
\hline Total amount & $\mathbf{1 6 , 5 0 0}$ & & $\mathbf{1 0 , 1 4 0}$ \\
\hline
\end{tabular}

Tab. 3 - Request of thermal power of $\mathrm{CH}$

Tab. 2 - Request of electrical power of $\mathrm{CH}$ 


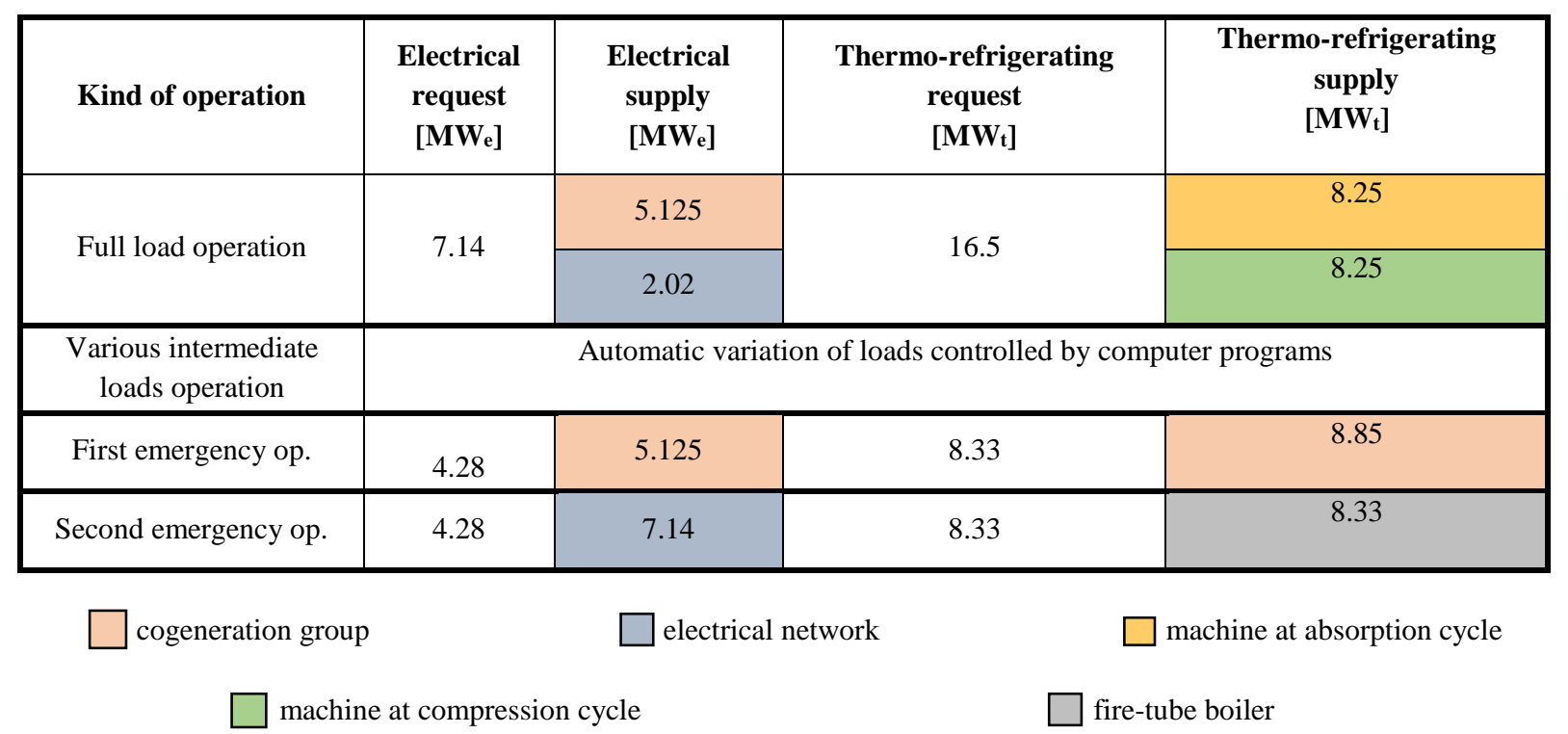

Fig.3 - Types of management

\section{Pollutants really discharged into atmosphere}

\section{Defining:}

Heat rate of turbogas (Fig.4) : 11,763.5 KJ/MWh

Electrical yearly energy produced by turbogas :

$5.25 \mathrm{MW} \cdot 6.133 \mathrm{~h}($ see tab. 1$)=32,198.25 \mathrm{MWh} /$ year

\begin{tabular}{|c|c|}
\hline \multicolumn{2}{|c|}{ Single-shaft SGT-100 for power generation } \\
\hline Power output & $5.05 \mathrm{MW}(\mathrm{e}) / 5.4 \mathrm{MW}(\mathrm{e})$ \\
\hline Fuel & $\begin{array}{l}\text { Natural gas / liquid fuel / dual fuel; other fuels on } \\
\text { request }\end{array}$ \\
\hline \multicolumn{2}{|c|}{$\begin{array}{l}\text { Automatic changeover from primary to secondary } \\
\text { fuel at any load }\end{array}$} \\
\hline Frequency & $50 / 60 \mathrm{~Hz}$ \\
\hline Electrical efficiency & $30.2 \% / 31.0 \%$ \\
\hline Heat rate & 11,914kJ/kWh / 11,613kJ/kWh \\
\hline Turbine speed & $17,384 \mathrm{rpm}$ \\
\hline Compressor pressure ratio & 14.0:1/15.6:1 \\
\hline Exhaust gas flow / temperature & $19.5 \mathrm{~kg} / \mathrm{s}, 545^{\circ} \mathrm{C} / 20.6 \mathrm{~kg} / \mathrm{s}, 531^{\circ} \mathrm{C}$ \\
\hline
\end{tabular}

Fig.4 [3]

From (1) and (2) it is possible to obtain :

$11,763.5 \cdot 32,198.25=378,764,113,875 \mathrm{KJ} /$ year $=$
$=378,764.114 \mathrm{GJ} /$ year

The value of $378,764.114 \mathrm{GJ} / \mathrm{year}$ is the thermal energy must be powered by combustion of methane to supply turbogas.

The mass of main pollutants in the case of combustion of $1 \mathrm{GJ}$ of methane [4] are:

$\left.\begin{array}{l}\mathrm{CO}_{2}: 50.95 \mathrm{~kg} / \mathrm{GJ} \\ \mathrm{NO}_{\mathrm{x}}: 4.201 \cdot 10^{-2} \mathrm{~kg} / \mathrm{GJ} \\ \mathrm{PM}_{10}: 2.0 \cdot 10^{-5} \mathrm{~kg} / \mathrm{GJ}\end{array}\right\}$

From (4) and (3) it is possible to calculate the amount of polluting emission for each kind of pollutant matter:

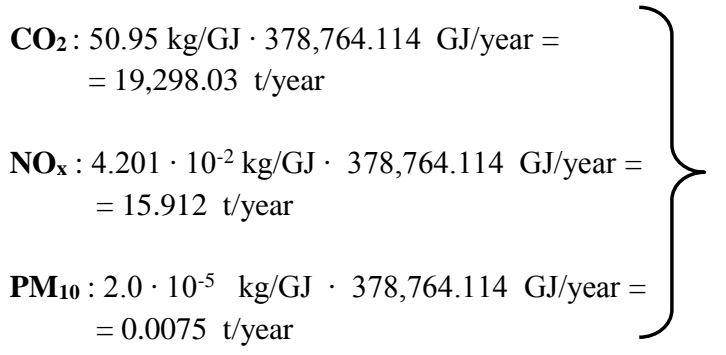

\section{Pollutants saved}

A. Pollutants coming from power station:

People calculate pollutants that could be discharged into atmosphere in the case to supply electricity from national electrical network in place of CCHP.

Tab.4 shows efficiency of electrical power station in function of type of fuel supply. In calculation people make use of an average efficiency.

\begin{tabular}{|c|c|c|c|}
\hline Fuel supply & & Efficiency & Average \\
\hline Oil & $=$ & 0.45 & \\
Coal & $=$ & 0.40 & 0.43 \\
\hline Methane & $=$ & 0.44 & \\
\hline
\end{tabular}

Tab.4

From (2) and Tab.4 it is possible to calculate the yearly electrical energy production:

32,198.25 MWh/year / $0.43=74,879.65 \mathrm{MWh} /$ year

Potential specific emission of each kind of fuel by public electrical network [5] is showed in (7): 
$\left.\begin{array}{l}\mathrm{CO}_{2}: 0.47 \mathrm{t} / \mathrm{MWh} \\ \mathrm{NO}_{\mathrm{x}}: 3.1 \cdot 10^{-4} \mathrm{t} / \mathrm{MWh} \\ \mathrm{PM}_{10}: 3.0 \cdot 10^{-6} \mathrm{t} / \mathrm{MWh}\end{array}\right\}$

Finally, from (6) and (7) people calculate the pollutants saved as showed in (8):

$$
\begin{aligned}
\mathbf{C O}_{2}: & 0.47 \mathrm{t} / \mathrm{MWh} \cdot 74,879.65 \mathrm{MWh} / \text { year }= \\
& =35,193.44 \mathrm{t} / \text { year }
\end{aligned}
$$

B. People calculate pollutants could be discharged into atmosphere in the case to utilize thermal generating station in place of CCHP system.

The need of thermal energy is showed in Tab.5. Tab.6 [ coming from (4) and Tab.5 ] shows for

\begin{tabular}{|c|c|c|c|c|c|}
\hline Utilization & Pollutant & [GJ/year] & [kg/GJ] & [kg/year] & [t/year] \\
\hline \multirow{3}{*}{ Hot sanitary water } & 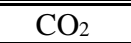 & \multirow{3}{*}{$22,469.4$} & 50.95 & $1,144,815.93$ & $1,144.8$ \\
\hline & $\mathrm{NO}_{\mathrm{x}}$ & & $4.201 \cdot 10^{-2}$ & 943.94 & 0.944 \\
\hline & $\mathrm{PM}_{10}$ & & $2.0 \cdot 10^{-5}$ & 0.45 & $4.5 \cdot 10^{-4}$ \\
\hline \multirow{3}{*}{$\begin{array}{c}\text { Absorption cooling } \\
\text { machines }\end{array}$} & $\overline{\mathrm{CO}_{2}}$ & \multirow{3}{*}{$33,403.10$} & "50.95 & "1,701,887.95 & $\overline{~ 1,701.9}$ \\
\hline & $\mathrm{NO}_{\mathrm{x}}$ & & $4.201 \cdot 10^{-2}$ & $1,404.26$ & 1.4 \\
\hline & $\mathrm{PM}_{10}$ & & $2.0 \cdot 10^{-5}$ & 0.67 & $6.7 \cdot 10^{-4}$ \\
\hline \multirow{3}{*}{$\begin{array}{l}\text { Post heating } \\
\text { (HVAC) }\end{array}$} & $\overline{\mathrm{C} \mathrm{CO}_{2}}$ & \multirow{3}{*}{$19,526.4$} & 50.95 & $9994,870.1$ & 9994.9 \\
\hline & $\mathrm{NO}_{\mathrm{x}}$ & & $4.201 \cdot 10^{-2}$ & 820.31 & 0.82 \\
\hline & $\mathrm{PM}_{10}$ & & $2.0 \cdot 10^{-5}$ & 0.39 & $3.9 \cdot 10^{-4}$ \\
\hline \multirow{3}{*}{$\begin{array}{l}\text { Hot separated } \\
\text { circuits }\end{array}$} & $\mathrm{CO}_{2}$ & \multirow{3}{*}{$2,445.12$} & 50.95 & $124,578.86$ & 124.6 \\
\hline & $\mathrm{NO}_{\mathrm{x}}$ & & $4.201 \cdot 10^{-2}$ & 102.72 & 0.103 \\
\hline & $\mathrm{PM}_{10}$ & & $2.0 \cdot 10^{-5}$ & 0.05 & $5.0 \cdot 10^{-5}$ \\
\hline \multirow{3}{*}{ Various utilities } & $\overline{\mathrm{CO}} \mathrm{CO}_{2}$ & \multirow{3}{*}{$5,346.00$} & 50.95 & $272,378.7$ & 272.4 \\
\hline & $\mathrm{NO}_{\mathrm{x}}$ & & $4.201 \cdot 10^{-2}$ & 224.59 & 0.225 \\
\hline & $\mathrm{PM}_{10}$ & & $2.0 \cdot 10^{-5}$ & 0.11 & $1.1 \cdot 10^{-4}$ \\
\hline
\end{tabular}
each utilization and for each pollutant the amount of pollutants.

\begin{tabular}{|c|c|c|c|c|c|}
\hline & POTENZA kW & h / day & day / year & TOT. [kWh/year] & TOT. [GJ/year] \\
\hline Hot sanitary water & 1,425 & 12 & 365 & $6,241,500$ & $22,469.4$ \\
\hline Absorption cooling machines & 12,887 & 8 & 120 & $9,278,640$ & $33,403.10$ \\
\hline Post heating (HVAC) & 5,650 & 6 & 120 & $5,424,000$ & $19,526.4$ \\
\hline Hot separated circuits & 1,415 & 8 & 120 & 679,200 & $2,445.12$ \\
\hline Various utilities & 1,650 & 3 & 300 & $1,485,000$ & $5,346.00$ \\
\hline Total amount & & & & $\mathbf{2 3 , 1 0 8 , 3 4 0}$ & $\mathbf{8 3 , 1 9 0 . 0 2 4}$ \\
\hline
\end{tabular}

Tab.5

Tab.6

Finally in (9), originated from Tab.6, people calculate total amount of saved emission for each kind of pollutants:

$$
\left.\begin{array}{rl}
\mathbf{C O}_{2}: & 1,144.8+1,701.9+994.9+124.6+ \\
& +272.4=4,238.6 \text { t/year } \\
\text { NO }_{\mathbf{x}}: & 0.944+1.4+0.82+0.103+ \\
& +0.225=3.492 \mathrm{t} / \text { year } \\
\text { PM }_{10}: & 4.5 \cdot 10^{-4}+6.7 \cdot 10^{-4}+3.9 \cdot 10^{-4} \\
& +5.0 \cdot 10^{-5}+1.1 \cdot 10^{-4}= \\
& =1.67 \cdot 10^{-3} \mathrm{t} / \text { year }
\end{array}\right\}
$$

\section{Environmental balance}

The amount coming from (5), (8) and (9) allows to have the final environmental global balance where negative values are attributed to pollutant matters really inserted in environment by combustion of fuel $\left(\mathrm{CH}_{4}\right)$ to supply turbogas, instead of positive values are attributed to theoretical pollutant matters in the case of energy supply by conventional technologies and plants. 


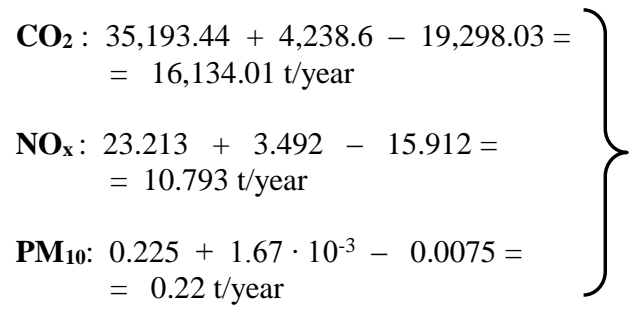

\section{Conclusion}

As showed previously in (10) design of EES pursuant to criteria of " $2^{\text {nd }}$ Law of Thermodynamics" and selecting CCHP techniques is a right way to decrease significantly impact of pollutants into atmosphere, especially for $\mathrm{CO}_{2}$ and $\mathrm{PM}_{10}$.

There is not a general methodology to design an EES; in fact the planning choice has general effectiveness as regard criteria of " $2^{\text {nd }}$ Law of Thermodynamics", whereas the practical consequence of CCHP techniques is convincing in application for this specific or that comparable cases that maintain specific values of ratio between electrical and thermal energy required.

It means that correct thermodynamics design of EES must take in account a lot of variable such as :

- Weather-climate and geographic position of locality of construction

- Types of activities that will carried out in built volumes

- Total amount of energy yearly required

- Possibility to exploit other renewable sources if locally present

- $\quad$ Etc. etc.

Only taking in consideration all previous variables, and other more, the designer will be able to conciliate the exploitation of energy and the care of environment.

\section{References}

[1] Patania F., Gagliano A., Nocera F., Agrifoglio A., "Techniques of CCHP as a right way to apply the $2^{\text {nd }}$ Law of Thermodynamic: case study (Part one)", $3^{\text {rd }}$ Global Academic Meeting (GAM), September 2015, New York, printing in progress in the European Scientific Journal (ESJ)

[2] Patania F., Manzo C., Gagliano A. \& Nocera F., "How to get Energy economics and environmental benefits, an applied research", III International Conference Economics and Management of Energy in Industry, April 2004, Lisbon, Portugal.

[3] Siemens Gas-Turbine catalogue - 2014

[4] iiSBE - SBT07-A Full DsnR3 http://www.iisbe.org/sbtool-2007 - November 07

[5] Governing Body of Piemonte Region (Italy) D.G.R. 43-11965 of 08.04.2009 attached document $\mathrm{B}$ 